Research article

\title{
Effect of various dormancy breaking treatments on seed germination, seedling growth and seed vigour of medicinal plants
}

\author{
Ashwani Kumar Bhardwaj, Sahil Kapoor, Avilekh Naryal, Pushpender Bhardwaj, \\ Ashish Rambhau Warghat, Bhuvnesh Kumar and Om Prakash Chaurasia* \\ Defence Institute of High Altitude Research, Defence Research \& Development Organization, Leh-Ladakh, \\ Jammu \& Kashmir, India
}

*Corresponding Author: opchaurasia1998@gmail.com

[Accepted: 20 September 2016]

\begin{abstract}
Study was conducted during 2013-14 to examine the role of various dormancy breaking treatments, viz. hot water treatment, scarification, stratification, concentrated acids $\left(\mathrm{H}_{2} \mathrm{SO}_{4}, \mathrm{HNO}_{3}\right.$ and $\mathrm{HCl}$ ), gibberellic acid, potassium nitrate, alcohol, and acetone and gamma-rays irradiation on the percentage germination, seedling growth and seed vigour. Dried seeds were incubated in the plant growth chambers for 20-28 days at constant temperature of $25 \pm 2{ }^{\circ} \mathrm{C}$ under continuous light (16 hrs) photoperiod after its treatments. Maximum percent germination $97.2 \%$ was obtained in Innula racemosa followed by Rheum webbianum (95.1\%), Carum carvi (93.4\%), Saussurea lappa $(90.01 \%)$ and Bunium persicum $(81.4 \%)$ when seeds were pretreated with acid $\left(\mathrm{H}_{2} \mathrm{SO}_{4}\right.$ for 5 minutes). According to results obtained in present study, all studied species found best germination with $\mathrm{H}_{2} \mathrm{SO}_{4}$ for 5 minutes in duration of 30 days. The seedlings derived from seeds exposed to the various treatments performed well when grown in a green house. Maximum length of seedlings were found in $24.3 \mathrm{~cm}$ in $S$. lappa followed by $R$. webbianum $(23.8 \mathrm{~cm})$ and $C$. carvi $(22.2 \mathrm{~cm})$ when seeds were pretreated with $\mathrm{H}_{2} \mathrm{SO}_{4}$ for 5 minutes, on the other side $B$. persicum $(19.4 \mathrm{~cm})$ in hot water treatment at $80^{\circ} \mathrm{C}$ for 20 minutes and $I$. racemosa $(17.4 \mathrm{~cm})$ in $0.2 \mathrm{KNO}_{3}$ for 10 minutes. Highest value of seed vigour index (2263) and lowest seed vigour index (390) was found in $R$. webbianum and B. persicum. The well developed seedlings were observed in 90 days and transplanted it for further developments. The data have implications for conservation and cultivation of the species studied.
\end{abstract}

Keywords: Acid treatment - Dormancy - Gibberellic acid - Nitric acid - Seed germination.

[Cite as: Bhardwaj AK, Kapoor S, Naryal A, Bhardwaj P, Warghat AR, Kumar B \& Chaurasia OP (2016) Effect of various dormancy breaking treatments on seed germination, seedling growth and seed vigour of medicinal plants. Tropical Plant Research 3(3): 508-516]

\section{INTRODUCTION}

Seed germination is a complex physiological processes that response to environmental signals such as water potential, light and other factors. Poor seed germination is the major limiting factor of threatened medicinal plants for large scale production and cultivation under cold desert conditions. Seed germination in general can be controlled by many factors like natural germination (growth) inhibitors (Angevine \& Chabot 1979). These are the derivatives of benzoic acid, cinnamic acid, coumarin, naringenin, jasmonic and abscisic acid (ABA). It has been postulated that seed coat (testa) of many plant species contains considerable amount of germination inhibitor, which prevent their seed germination (Arora \& Bhojwani 1989). The first stage of germination consists of ingesting water and an awakening or activation of the germplasm. Protein components of the cells that were formed as the seed developed became inactive as it matured. Seed germination is important to know the germination pattern of a plant, more particularly the medicinal ones that might need to bring under cultivation for the primary healthcare system. The significance of the seedling in plant population ecology has long been recognized (Baskin \& Baskin 1998). The germination response pattern of seeds is also regarded as a key characteristic in plant life history strategy (Baskin et al. 1993, Baskin \& Baskin 1972). The variation in seed 
dormancy and the subsequent patterns of seedling emergence are controlled by environmental conditions. Important factors controlling the variation seed dormancy within species include the environment of the mother plant during the time of seed maturation and environmental conditions after the seeds have been released (Bewley 1997). Certain environmental conditions may be required to break dormancy, and other conditions are often required to permit germination after dormancy is broken (Bewley \& Black 1994). Seeds of many species require days, weeks, or months at low temperatures to break dormancy (Bradbeer 1992), whereas others require warm temperatures for after-ripening to germinate when permissive conditions arrive (Chauhan \& Johnson 2008).

In some temperate species, dormancy is broken by a period of warm temperatures followed by cold stratification. This response is most often associated with morpho-physiological dormancy; however, seeds with morphophysiological dormancy have under developed embryos (Durrani et al. 1997). In order to accelerate this method, it can be combined with some treatments such as chemical applications or mechanical seed coat removal (El-Barghathi \& El-Bakkosh 2005, Fenner \& Thompson 2005). Many investigators have studied the effects of exogenous growth regulators on seed germination. Gibberellins eliminated the chilling requirements of peach and apple seeds and increased their germination (El-Barghathi \& El-Bakkosh 2005). Recent studies have revealed that cold stratification has a direct effect on production of gibberellins (GAs) in seeds of Arabidopsis thaliana (Fernandez et al. 2002, Hartmann et al. 1997). Exogenously applied GA overcomes seed dormancy in several species (Hassan \& Fardous 2003, Hradilik \& Cisarova 1975) and promotes germination in some species that normally require cold stratification, light, or after-ripening (Kandari et al. 2012). Pre-chilling, scarification, and treatments with gibberellic acid $\left(\mathrm{GA}_{3}\right)$ or nitric acid $\left(\mathrm{KNO}_{3}\right)$ are the standard procedures used to enhance seed germination of dormant seeds.

However, many attempts have been made to investigate seed germination and seedling emergence of different annual and perennial species including medicinal plants (Bewley 1997, Liebst \&scheneller2008, Liza et al. 2010; Martinez-Gomez \&dicenta 2001, Mayer \& Poljakoff-mayber 1989, Mehanna et al. 1985). However, no study has surveyed germination patterns in medicinal plants from Ladakh region of India.

\section{MATERIALS AND METHODS}

Seed source

Fruits of S. lappa, R. webbianum, I. racemosa, C. carvi and B. persicum were collected from their localities at an altitude of 1500-4000 m of Ladakh region of India in August 2012 (Table 1). The seeds were later air dried and stored at room temperature $\left(25^{\circ} \mathrm{C}\right)$ before experimentation.

Table 1. Brief description of plant species studied.

\begin{tabular}{|c|c|c|c|c|c|}
\hline Name/Family & Local name & Habit & Habitat & Altitude (m) & Uses \\
\hline $\begin{array}{l}\text { Saussurea lappa C.B } \\
\text { Clarke (Asteraceae) }\end{array}$ & Kuth & $\begin{array}{l}\text { Perennial } \\
\text { shrub }\end{array}$ & $\begin{array}{l}\text { Cultivated land \& waste } \\
\text { land (Lahaul valley) }\end{array}$ & $2600-3600$ & $\begin{array}{l}\text { Roots used as anti-arthritic, } \\
\text { antiseptic, aphrodisiac, } \\
\text { carminative and digestive } \\
\text { agent }\end{array}$ \\
\hline $\begin{array}{l}\text { Rheum webbianum } \\
\text { Royle (Polygonace) }\end{array}$ & Lachoo & $\begin{array}{l}\text { Perennial } \\
\text { herb }\end{array}$ & $\begin{array}{l}\text { Moist slopes \& open } \\
\text { slopes (Zanskar valley) }\end{array}$ & $3300-5200$ & $\begin{array}{l}\text { Roots, stem and petioles used } \\
\text { as appetizer, astringent and } \\
\text { in the treatment of asthma, } \\
\text { bronchitis, eye diseases, } \\
\text { piles, etc. }\end{array}$ \\
\hline $\begin{array}{l}\text { Inula racemosa Hook. } \\
\text { (Asteraceae) }\end{array}$ & Pushkarmool & $\begin{array}{l}\text { Perennial } \\
\text { shrub }\end{array}$ & $\begin{array}{l}\text { Cultivated land (Indus \& } \\
\text { Lahaul valley) }\end{array}$ & $1595-2800$ & $\begin{array}{l}\text { Roots used as anthelmintic, } \\
\text { antiseptic, anti-inflammatory } \\
\text { and diuretic agents }\end{array}$ \\
\hline $\begin{array}{l}\text { Carum carvi Linn. } \\
\text { (Apiaceae) }\end{array}$ & $\begin{array}{l}\text { Gonyor, } \\
\text { jirah }\end{array}$ & $\begin{array}{l}\text { Biennial or } \\
\text { annual herb }\end{array}$ & $\begin{array}{l}\text { Cultivated land or water } \\
\text { streams (Indus \& spiti } \\
\text { valley) }\end{array}$ & $3650-3900$ & $\begin{array}{l}\text { Fruits/seeds used as spice, } \\
\text { carminative, back pain, liver } \\
\text { problem and stimulant }\end{array}$ \\
\hline $\begin{array}{l}\text { Bunium persicum } \\
\text { (Boiss.) B. Fedtsch. } \\
\text { (Apiaceae) }\end{array}$ & Kala jirah & $\begin{array}{l}\text { Perennial } \\
\text { herb }\end{array}$ & $\begin{array}{l}\text { Rocky slopes } \\
\text { (Suru valley) }\end{array}$ & $1800-3500$ & $\begin{array}{l}\text { Fruits/seeds used as spice, } \\
\text { carminative, back pain, liver } \\
\text { problem and stimulant }\end{array}$ \\
\hline
\end{tabular}

Seed viability assessment

To ensure that the seeds used for the experiment were viable and of high quality, the sample lots were subjected to viability test using the tetrazolium technique. Three replicates (20 seeds each replicate) were 
subjected to 2, 3, 5, triphenyl tetrazolium chloride (TTC) test after 15, 30, 45, 60 days of storage at $4^{\circ} \mathrm{C}$. In this method, seeds were longitudinally sectioned and the sections were immersed in a $0.5 \%$ aqueous solution of TTC $\left(\mathrm{pH}\right.$ 6.5) for $24 \mathrm{hrs}$ at room temperature $\left(25^{\circ} \mathrm{C}\right)$ under controlled dark conditions. The TTC solution was drained and sections were rinsed 3 times with tap water. The topographical staining pattern of the embryos and cotyledons were studied under a dissection microscope.

Seed surface sterilization and germination assessments

Seeds of S. lappa, R. webbianum, I. racemosa, C. carvi and B. persicum were sterilized using $0.04 \%$ aqueous solution of mercuric chloride $\left(\mathrm{HgCl}_{2}\right)$ for $15 \mathrm{sec}$. to remove any fungal infection and then rinsed with distilled water. Three replications of 30 seeds each were prepared for each treatment and control. $\mathrm{T}_{1}$, Seeds were dipped in concentrated acids, i.e. $\mathrm{H}_{2} \mathrm{SO}_{4}$ for $5 \mathrm{~min}$; $\mathrm{T}_{2}$, gamma rays irradiation of seeds at different doses (i.e. 10-50 KR) using the 60Co gamma cell irradiator facility at the Physics Department, RTM, Nagpur University, Nagpur followed by dipping in concentrated $\mathrm{H}_{2} \mathrm{SO}_{4}$ for $5 \mathrm{~min}$. ; $\mathrm{T}_{3}$, seeds were first pretreated in concentrated $\mathrm{H}_{2} \mathrm{SO}_{4}$ for $10 \mathrm{~min}$. further dipped in $\mathrm{GA}_{3}$ solutions (i.e. $200 \mathrm{ppm}$ ) for a period of $1 \mathrm{hr} ; \mathrm{T}_{4}$, seeds were soaked at 3 different doses of $\mathrm{KNO}_{3}$ (i.e. $0.1,0.2$ and $0.3 \%$ ) for $10 \mathrm{~min}$. after presoaking in concentrated $\mathrm{H}_{2} \mathrm{SO}_{4}$ for 10 min; $\mathrm{T}_{5}$, scarification of seeds by P320A sandpaper (sand grain. $\mathrm{cm}^{-2}$ ) then dipped in $\mathrm{GA}_{3}$ solutions (i.e. $200 \mathrm{ppm}$ ) for a period of $1 \mathrm{hr}$; T6, seeds were stratified at $-20^{\circ} \mathrm{C}$ for $1-30$ days; T7, seeds were dipped in the hot water at $80^{\circ} \mathrm{C}$ for 20 minutes. and T8, seeds were first soaked in absolute alcohol and acetone for 10 minutes. All the treated seeds were placed in closed $9 \mathrm{~cm}$ Petridishes $(\varnothing 9 \mathrm{~cm})$ which were lined with 2 sheets of filter papers Whatman No.1 and moistened with sterilized MilliQ water. Treated seeds were placed on the moist paper for germination for 20-28 days and light was provided by philips daylight lamps $\left(324 \mu \mathrm{mol} . \mathrm{m}^{-2} . \mathrm{s}^{-1}\right)$. A clear labeled lid was placed on top of each Petri-dish denoting the treatment, temperature and replication. All these Petri-dish were then kept in plant growth chamber at $25 \pm 2{ }^{\circ} \mathrm{C}$ with relative humidity of $65 \%$ and $16 \mathrm{hr}$ of light. Petri dishes were checked daily for germinated seeds and filter paper was moistened with sterilized MilliQ water as needed. Germination was determined by observing a visible radical or shoot. The number of seeds used for the germination tests were 3 replications $\times 90$ seeds/replication for each treatments.

Seedling growth \& vigour

Seedling were incubated in plant growth chamber and monitored weekly. The growth of seedling was measured by vernier caliper in $\mathrm{cm}$ after 30 days of incubation. The well developed seedlings were potted in potting mixture containing Coconut + vermiculite + perlite $(1: 1: 1)$ under controlled green house conditions. Initially, for 5-10 days the developed seedlings were covered with glass jars to provide sufficient moisture for growth of new shoots. During transplanting process, jars were taken off every day for $1-2 \mathrm{hr}$ to acclimatize the plantlets to the external conditions. Seed vigour Index (SVI): Germination percentage $\times$ Seedling length $(\mathrm{cm})$. Experiments were performed in triplicate.

\section{Data analysis}

The data were statistically analyzed as a factorial experiment based on completely randomized design with three replicates. Means were compared by one-way ANOVA using SPSS for windows (Version 21.0) and differences between the means were compared by Duncan's multiple range test (DMRT). A probability of $\leq 0.05$ was considered significant.

\section{RESULTS AND DISCUSSION}

Seed viability

Tetrazolium chloride test showed the percentage viability of S. lappa, R. webbianum, I. racemosa, C. carvi and $B$. persicum as 88, 72, 78, 81 and 75 at the day of harvesting, which remains 55, 51, 55, 58 and 57 percent by 60 days of storage, showing a continuous decline with storage period (Fig. 1). A continuous decrease in seed viability was observed of different rhizomatous herbs of Himalayan region with storage period (Pupalla \& Fowler 2002, Sharma et al. 2006) which supplemented the present observation.

\section{Seed germination assessments}

Mean and standard error comparisons of each treatment are based on Duncan's test as presented in table 2. The effect of various durations of concentrated $\mathrm{H}_{2} \mathrm{SO}_{4}$ showed a positive effect of $\mathrm{H}_{2} \mathrm{SO}_{4}$ on seed germination, while no significant germination was observed with concentrated $\mathrm{HCl}$. In case of concentrated $\mathrm{HNO}_{3}$ treatment there was no seed germination at all. Maximum germination of $97.2 \%$ was observed in I. racemosa with 5 
minutes of soaking in concentrated $\mathrm{H}_{2} \mathrm{SO}_{4}$ followed by $95.1 \%, 93.4 \%, 90 \%$ and $81.4 \%$ in $R$. webbianum, C. carvi, S. lappa and B. persicum (Table 2 \& Fig. 2). However, any increase or decrease in acid soaking time significantly reduced the seed germination which can be attributed to embryo damage. Poor germination or no germination in case of concentrated $\mathrm{HCl}$ and $\mathrm{HNO}_{3}$ respectively might be due to the inability of these treatments to break the physical dormancy. Also, the positive effect of gamma rays irradiation on seed germination is already known in many crops. Therefore, seeds were also treated with different doses of gamma rays along with concentrated $\mathrm{H}_{2} \mathrm{SO}_{4}$ treatment for 5 minutes. Maximum germination of $81.96 \%$ was observed when seeds of $C$. carvi were treated with $30 \mathrm{Kr}$ gamma rays, followed by $5 \mathrm{~min}$. concentrated $\mathrm{H}_{2} \mathrm{SO}_{4}$ treatment, followed by $77 \%$, 76.4\%, 73.04\% and $45.6 \%$ in B. persicum, S. lappa, I. racemosa and R. webbianum. Obviously, any further increase or decrease dose of gamma rays or $\mathrm{H}_{2} \mathrm{SO}_{4}$ duration showed negative effect on the overall percent germination (Table 2 \& Fig. 2).

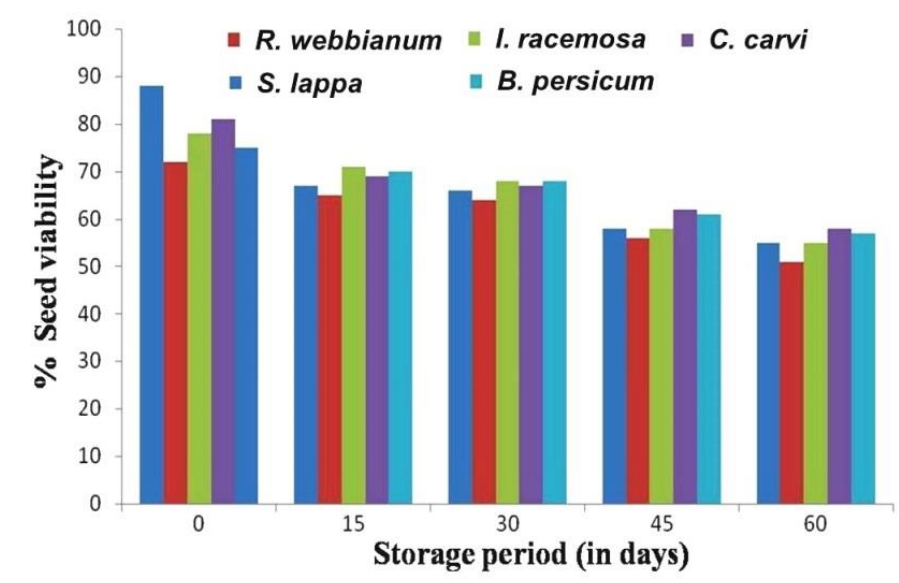

Figure 1. Decrease in seed viability of some medicinal plants during storage at $4^{\circ} \mathrm{C}$ with increase in storage period.
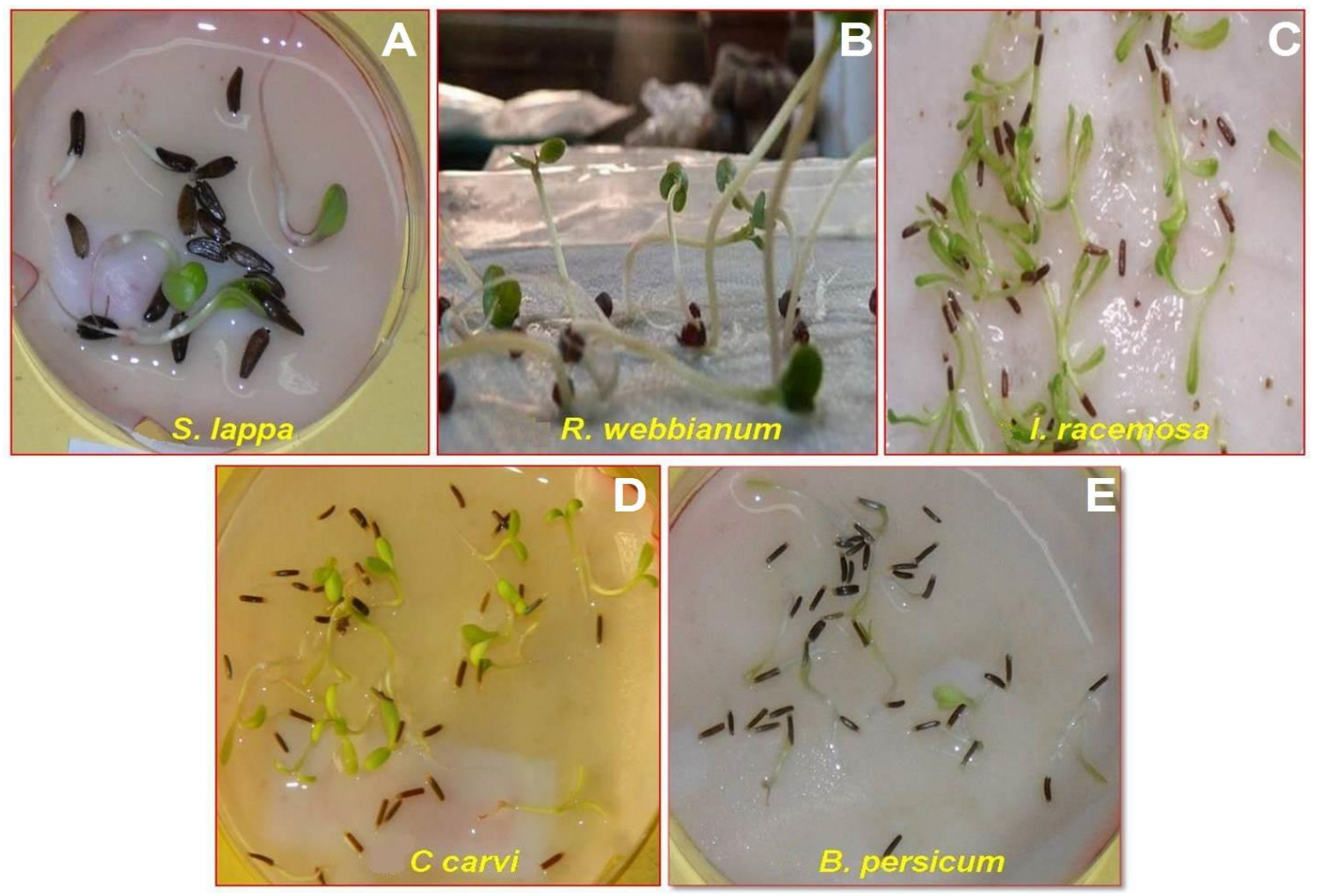

Figure 2. Seed germination of some selected medicinal plants.

Gibberellic acid is also known to play an essential role in seed germination, stem elongation and flower development (Sharma et al. 2006). However, we have tried 100-500 ppm solution of $\mathrm{GA}_{3}$ out of which $200 \mathrm{ppm}$ showed significant results. 200 ppm of $\mathrm{GA}_{3}$ treatment showed the highest germination of $69.20 \%$ in $C$. carvi when seed treated with $1 \mathrm{hr}$ soaking in $\mathrm{GA}_{3}$ alongwith 10 min. of $\mathrm{H}_{2} \mathrm{SO}_{4}$ pre-soaking followed by $62 \%, 59.6 \%$, www.tropicalplantresearch.com 


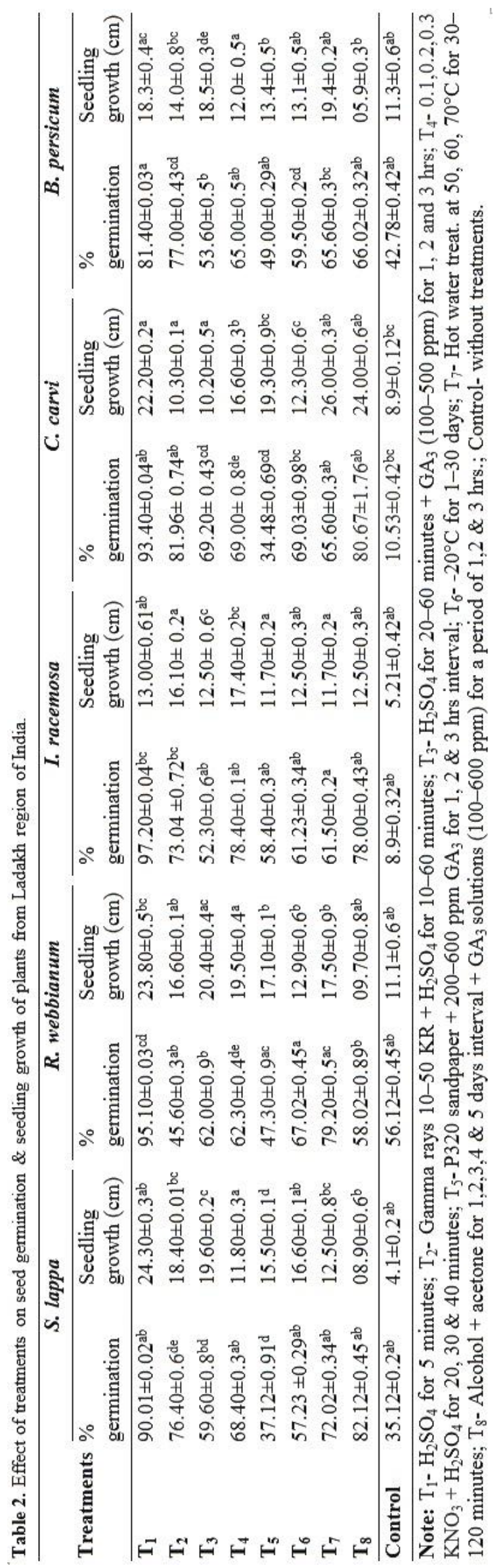

www.tropicalplantresearch.com 
$53.6 \%$ and $52.3 \%$ in $R$. webbianum, S. lappa, B. persicum and I. racemosa (Table $2 \&$ Fig. 2). This means that the regulation of endogenous gibberellic levels after seed imbibitions along with specific $\mathrm{H}_{2} \mathrm{SO}_{4}$ presoaking time of 10 minutes is crucial factor in determining the seed germination. Lesser or longer treatment time was inhibitory in each case. A chemical treatment such as pre-treatment with $\mathrm{H}_{2} \mathrm{SO}_{4}$ for $15-30$ minutes was found to be an effective method to increase germination. While seed treatments with $\mathrm{KNO}_{3}$ or $\mathrm{GA}_{3}$ is known to enhance the germination percentage (Silvertown \& Lovett Doust 1993). When $\mathrm{H}_{2} \mathrm{SO}_{4}$ pre-treated seeds of $I$. racemosa were treated with $\mathrm{KNO}_{3}$ in different combinations the highest germination of $78.4 \%$ (Table 2 \& Fig. 2) was obtained in case of pre-soaking in concentrated $\mathrm{H}_{2} \mathrm{SO}_{4}$ (for 10 minutes), followed by dipping in $\mathrm{KNO}_{3}(0.2 \%$ for 10 minutes). While, decreasingly $69 \%, 68.4 \%, 65 \%$ and $62.3 \%$ found in C. carvi, S. lappa, B. persicum and $R$. webbianum. Any increase or decrease in the concentration of $\mathrm{KNO}_{3}$ or soaking duration along with further increase in the presoaking time showed negative effect on the overall percent germination. Unsatisfactory germination percentage i.e. less than 20 was found in $0.3 \% \mathrm{KNO}_{3}$ for 10 min. along with $10 \mathrm{~min} \mathrm{H}_{2} \mathrm{SO}_{4}$ presoaking.

Scarification, stratification and hot water treatments were also found satisfactory results. Application of alcohol, acetone and $\mathrm{HNO}_{3}$ although broke the seed coat but not found better germination as compared to other treatments. Sulfuric acid treatment to remove mucilage and soaking in either of $\mathrm{KNO}_{3}, \mathrm{GA}_{3}$ or gamma ray treatment was found effective to allow penetration of oxygen from the surroundings to the embryos and increased germination of seeds. Germination in each case was superior over the control (10-20\%). Maximum germination percentage i.e. $69.03 \%$ was found in C. carvi when seeds were stored at $-20^{\circ} \mathrm{C}$ for 30 days followed by $67.02 \%, 61.23 \%, 59.5 \%$ and $57.23 \%$ in R. webbianum, I. racemosa, B. persicum and S. lappa. On the other hand, maximum percent germination $(79.2 \%)$ found in $R$. webbianum when seeds treated with hot water at $80^{\circ} \mathrm{C}$ for $20 \mathrm{~min}$. followed by $72.02 \%, 65.6 \%, 65.6 \%$ and $61.5 \%$ in S. lappa, C. carvi, B. persicum and I. racemosa while, $82.12 \%$ germination found in $S$. lappa when seeds treated with alcohol and acetone for 10 min. followed by $80.67 \%, 78 \%, 66.02 \%$ and 58.02\% in C. carvi, I. racemosa, B. persicum and R. webbianum (Table 2 \& Fig. 2 ). The responses of seeds to different treatments were strongly species-specific. It is obvious from the present data and similar work reported by other authors that the responses of dormant seeds of the same species to different factors are variable, depending upon the habitat of collection and duration of storage. However, some reported $70 \%$ germination in $S$. lappa when seeds were treated with gibberellic acid (GA) (3 $\mu \mathrm{M})$ (Tairu et al. 2007). $89 \%$ germination was observed in $R$. webbianum when seeds were treated with $\mathrm{GA}_{3}$ and $\mathrm{KNO}_{3}\left(\mathrm{Taiz}_{2} \&\right.$ Zeiger 2010). Similar to our observations, effectiveness of low temperature in causing dormancy removal has also been reported in other populations of C. carvi (Vleeshouwers et al. 1995) and B. persicum (Warghat et al. 2014). The low temperature requirement appeared to be replaced by $\mathrm{GA}_{3}$ in $I$. racemosa and C. carvi, but not in $B$. persicum, further signifying the species specificity in responses even of closely related species. Lowtemperature treatment of seeds could be easily adopted for the cultivation of species wherever it proved effective. According to results obtained in present study, all studied species found best germination with $\mathrm{H}_{2} \mathrm{SO}_{4}$ for 5 minutes in duration of 30 days and significantly different as compared to other treatments at $5 \%$ level.

\section{Seedling growth and vigour index}

The effect of various durations of concentrated $\mathrm{H}_{2} \mathrm{SO}_{4}$ showed a positive effect of $\mathrm{H}_{2} \mathrm{SO}_{4}$ on seedling growth. The maximum length of seedling of $S$. lappa was observed $24.3 \mathrm{~cm}$, when seeds were treated with $\mathrm{H}_{2} \mathrm{SO}_{4}$ for 5 minutes while, minimum length found $8.9 \mathrm{~cm}$ when seeds treated with alcohol and acetone for 10 minutes. Whereas, in $R$. webbianum maximum $(23.8 \mathrm{~cm})$ \& minimum $(9.7 \mathrm{~cm})$, I. racemosa maximum $(17.4$ $\mathrm{cm})$ in $\mathrm{KNO}_{3} \& \mathrm{H}_{2} \mathrm{SO}_{4}$ treatment and minimum $(11.7 \mathrm{~cm})$ in $\mathrm{GA} 3$ treatment, $C$. carvi maximum $(22.2 \mathrm{~cm})$ and minimum $(10.2 \mathrm{~cm})$ in $\mathrm{H}_{2} \mathrm{SO}_{4}+\mathrm{GA}_{3}$ treatment and in $B$. persicum maximum $(19.4 \mathrm{~cm})$ in hot water treatment and minimum $(5.9 \mathrm{~cm})$ in alcohol + acetone for 10 minutes. Similar type of effects of treatments on seedlings growth of $Q$. coccifera was also found (Arora \& Bhojwani 1989). There was a significant difference among the different treatments and medicinal plant seeds on seedling vigour (Table 3). R. webbianum significantly produced the best seedling vigour index 2263 which is statistically different from the other medicinal plants and treatments. However, B. persicum produced seedlings with low vigour index of 390. The bigger sized seed of $R$. webbianum with $\mathrm{H}_{2} \mathrm{SO}_{4}$ treatment for 5 min. statistically produced seedling of very high vigour index of 2263 compared to small sized seed of $B$. persicum with alcohol + acetone treatment for 10 min. which produced seedling that have low vigour index of 390. However, bigger sized seeds of $R$. webbianum and $S$. lappa produced the more stem girth compared to the small sized seed of B. persicum that gave less stem girth. The 
better seedling growth with $\mathrm{H}_{2} \mathrm{SO}_{4}$ treatment for $5 \mathrm{~min}$. could be as a result of the early germination recorded and the maintenance of continuous growth and vigour with these treatments, during the period of observation.

\begin{tabular}{llllll}
\multicolumn{6}{l}{ Table 3. Seed vigour index of medicinal plants. } \\
\hline Treatments & S. lappa & R. webbianum & I. racemosa & C. carvi & B. persicum \\
\hline $\mathbf{T}_{\mathbf{1}}$ & 2187 & 2263 & 1264 & 2073 & 1490 \\
$\mathbf{T}_{\mathbf{2}}$ & 1406 & 757 & 1176 & 844 & 1078 \\
$\mathbf{T}_{\mathbf{3}}$ & 1168 & 1265 & 654 & 706 & 992 \\
$\mathbf{T}_{\mathbf{4}}$ & 807 & 1215 & 1364 & 1145 & 780 \\
$\mathbf{T}_{\mathbf{5}}$ & 575 & 809 & 683 & 665 & 657 \\
$\mathbf{T}_{\mathbf{6}}$ & 950 & 865 & 765 & 849 & 779 \\
$\mathbf{T}_{\mathbf{7}}$ & 900 & 1386 & 720 & 1207 & 1273 \\
$\mathbf{T}_{\mathbf{8}}$ & 731 & 563 & 975 & 1146 & 390 \\
\hline Control & 143 & 622 & 46 & 94 & 483 \\
\hline
\end{tabular}

As the seed size increases there was more food reserved in cotyledon of the seed to sustain the seedling growth than the smaller seed sizes whose food reserved could be exhausted thus affecting the seedling growth and vigour. This is agreed with the work previously done (Yamaguchi \& Kamiya 2000). The significantly maximum seedling length obtained by $S$. lappa and $R$. webbianum could be that there were enough spaces within the treatments that allow growth. The maximum seedling length produced by the big sized seeds could be as results of its radicles where roots can easily attach themselves (Yamaguchi \& Kamiya 2002). After the $90^{\text {th }}$ days, the well developed seedlings were transplanted to green house condition at DIHAR, Leh and placed under shade for further growth and development. However, result accomplished that $80 \%$ survival rate in green house condition and $70 \%$ in open condition of herbal garden with well developed healthy plantlets (Fig. 3). Similarly, It was found that survival rate of seedlings in the green house was high in S. lappa, R. webbianum and low in I. racemosa, $C$. carvi and $B$ persicum (Yamaguchi \& Kamiya 2002). Ten month old plants of these species are shown in figure 3 . The transplanted seedlings of $B$. persicum and $C$. carvi did not survive beyond three month.
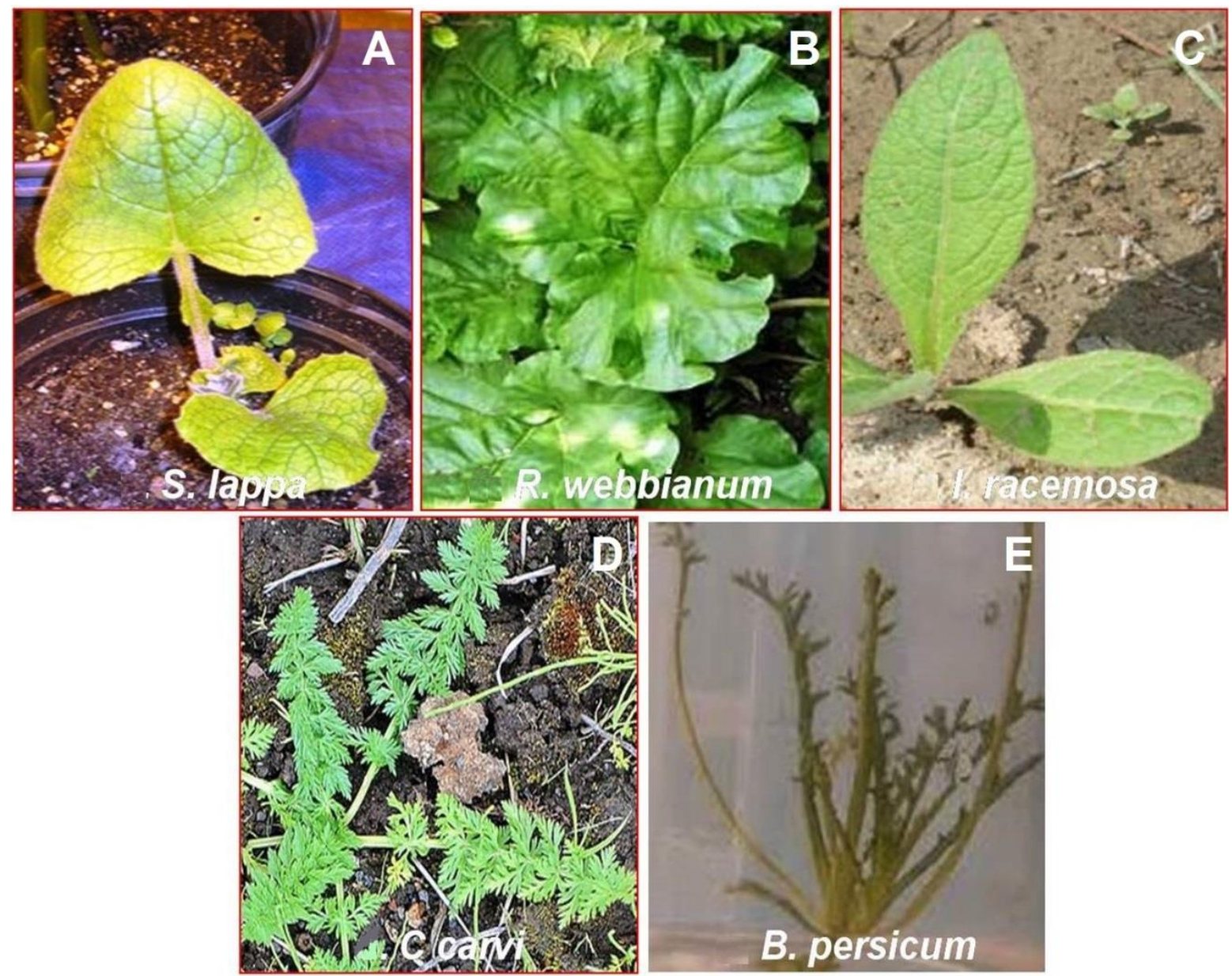

Figure 3. A \& E, Seed-derived seedlings in petridish. B-D, Ten-month old plants growing under green house conditions. www.tropicalplantresearch.com 


\section{CONCLUSIONS}

Plant propagation multiplies plants in bulk and preserves their essential genetic characteristics. Acid scarification, followed by gamma rays, addition of $\mathrm{GA}_{3}$ or $\mathrm{KNO}_{3}$ solution and hot water is a simple, efficient and cost-effective method for ensuring better seed germination and well developed seedlings. The outcomes of the present study can be gainfully utilized for multiplication of the species. The information will prove beneficial not only for conservation of species but also in boosting rural economy and the information will prove beneficial for other related species.

\section{ACKNOWLEDGEMENTS}

Authors are thankful to Defence Research and Development Organization (DRDO), Ministry of Defence, Government of India for providing financial assistance for the research. We are also thankful to Mr. Sandeep Singh Rawat for laboratory help.

\section{REFERENCES}

Angevine R \& Chabot BF (1979) Seed germination syndromes in higher plants In: Solbrig OT, Jain S, Johnson GB \& Raven PH (eds) Topics in Plant Population Biology. Columbia University Press, New York, pp. 188206.

Arora R \& Bhojwani SS (1989) In vitro propagation and low temperature storage of Saussurea lappa C.B. Clarke - an endangered medicinal plant. Plant Cell Report 8: 44-47.

Baskin CC \& Baskin JM (1998) Seeds, ecology, biogeography, and evolution of dormancy and germination. Academic Press, San Diego.

Baskin CC, Chesson PL \& Baskin JM (1993) Annual seed dormancy cycles in two desert winter annuals. Journal of Ecology 81: 551-556.

Baskin JM \& Baskin CC (1972) Ecological life cycle and physiological ecology of seed germination of Arabidopsis thaliana. Canadian Journal of Botany 50: 353-360.

Bewley JD (1997) Seed germination and dormancy. Plant Cell 9: 1055-1066.

Bewley JD \& Black M (1994) Seeds Physiology of Development and Germination. Plenum Press, New York, USA.

Bradbeer LB (1992) Vegetable production and their uses. Africana publication limited Lagos, Nigeria, pp. 6770.

Chauhan BS \& Johnson DE (2008) Influence of environmental factors on seed germination and seedling emergence of Eclipta (Eclipta prostrata) in a tropical environment. Weed Science 56: 383-388.

Durrani MJ, Qadir SA, Farrulch H \& Hussain F (1997) Germination ecology of Bunium persicum (Boiss) Fedtsch and Ferula oopoda (Boiss and Bulse) Boiss. Hamdard-Medicus 40, 86-90.

El-Barghathi MF \& El-Bakkosh A (2005) Effect of some mechanical and chemical pre-treatments on seed germination and seedling growth of Quercus coccifera (Kemes Oaks). Jerash Private University.

Fenner M \& Thompson K (2005) The ecology of seeds. Cambridge University Press, New York.

Fernandez H, Perez C, Revilla MA \& Perez-Gar-cia F (2002) The levels of $\mathrm{GA}_{3}$ and $\mathrm{GA}_{20}$ may be associated with dormancy release in Onopordum nervosum seeds. Plant Growth Regulation 38(2): 141-143.

Hartmann HT, Kester DE, Davies Jr F \& Genève RL (1997) Plant Propagation Principles and Practices, Sixth Edition. New Jersey, Prentice Hall.

Hassan MA \& Fardous Z (2003) Seed germination, pollination and phenology of Gloriosa superba L. (Liliaceae). Bangladesh Journal of Plant taxonomy 10(1): 95-97.

Hradilik J \& Cisarova H (1975) Studies on the dormancy of caraway (Carum carvi) achenes. Rostlinna. Vyroba 21: 351-364.

Kandari LS, Rao KS, Payal KC, Maikhuri RK, Chandra A \& Vanstaden JV (2012) Conservation of aromatic medicinal plant Rheum emodi Wall ex Messi. through improved seed germination. Seed Science \& Technology 40: 95-101.

Liebst B \& Schneller JS (2008) Seed dormancy and germination behavior in two Euphrasia species (Orobanchaceae) occurring in the Swiss Alps. Botanical Journal of the Linnean Society 156: 649-656.

Liza SA, Rahman MO, Uddin MZ, Hassan MA \& Begum M (2010) Reproductive biology of three medicinal plants. Bangladesh Journal of Plant taxonomy 17(1): 69-78. 
Martinez-Gomez P \& Dicenta F (2001) Mechanisms of dormancy in seeds of peach (Prunus persica (L.) Batsch) cv. GF 305. Scientia Horticulturae 91: 51-58.

Mayer AM \& Poljakoff-Mayber A (1989) The germination of seeds. Pergamon Press, New York, NY.

Mehanna HT, Martin GC \& Nishijuma C (1985) Effects of temperature, chemical treatments and endogenous hormone content on peach seed germination and subsequent seedling growth. Scientia Horticulturae 27: 6373.

Pupalla N \& Fowler JI (2002) Lesquerella seed pre-treatment to improve germination. Industrial Crops and Products 17: 61-9.

Sharma RK, Sharma S \& Sharma SS (2006) Seed germination behavior of some medicinal plants of Lahaul and Spiti cold desert (Himachal Pradesh): implications for conservation and cultivation. Current Science 90(8): 1113-1118.

Silvertown JW \& Lovett Doust J (1993) Introduction to plant population biology, $3^{\text {rd }}$ edition. B1ackwell Scientific Publications, Oxford, 210 pp.

Tairu FM, Adu AO \& Adegbemile CM (2007) Effects of sowing media and depth on transplant quality of garden egg (Solanum gilo L). NIHORT Ibadan, in- house review meeting.

Taiz L \& Zeiger E (2010) Plant Physiology. Sinauer Associates Inc., USA.

Vleeshouwers LM, Bouwmeester HJ and Karssen CM (1995) Redefining seed dormancy: an attempt to integrate physiology and ecology. Journal of Ecology 83: 1031-1037.

Warghat AR, Bajpai PK, Srivastava RB, Chaurasia OP, Chauhan RS \& Sood H (2014) In vitro protocorm development and mass multiplication of an endangered orchid, Dactylorhiza hatagirea. Turkish Journal of Botany 38: 737-746

Yamaguchi S \& Kamiya Y (2000) Gibberellin biosynthesis: Its regulation by endogenous and environmental signals. Plant Cell Physiology 41: 251-257.

Yamaguchi S \& Kamiya Y (2002) Gibberellins and light-stimulated germination. Journal Plant Growth Regulation 20: 369-376. 